Janusz Zrobek

\title{
Marketing terytorialny a rozwój terenów wiejskich
}

\section{Wstęp}

Tereny wiejskie w większości są zaliczane do obszarów słabo rozwiniętych, o niskim potencjale rozwojowym. Przełamanie marginalizacji gospodarczej tych terenów wymaga jednak wysokiego tempa rozwoju, opartego na aktywności i przedsiębiorczości ich władz i mieszkańców. Wskazane są zatem nowoczesne formy aktywności, pozwalające na lepsze wykorzystanie ich potencjału, stymulujące rozwój gospodarczy. Poszukiwanie i wdrażanie środków służących rozwojowi przestrzeni wiejskiej staje się kluczowym elementem poprawienia ich potencjału społeczno-ekonomicznego. Oddziaływanie na rozwój wsi wymaga wsparcia środkami intensyfikującymi możliwości pełniejszego osiągania korzyści płynących z zachodzących procesów.

Podbudową tego typu aktywności może być wykorzystanie działań marketingowych. Stanowią one skuteczny sposób zarządzania, stymulujący sprawne funkcjonowanie danej jednostki terytorialnej, umożliwiający pozyskanie i utrzymanie potrzebnych środków. Przyjęcie przez samorządy wiejskie orientacji marketingowej pozwala na przyspieszenie rozwoju i zwiększenie adaptacyjności do wymagań współczesnej gospodarki. Używanie zasad marketingu w zarządzaniu przestrzenią wiejską poprawia jej konkurencyjność i możliwości rozszerzenia kontaktów gospodarczych poszczególnych jednostek terytorialnych. Ich zastosowanie przyczynia się do zwiększenia możliwości rozwoju i wykorzystania innowacyjności dla postępu cywilizacyjnego na wsi.

Marketing stał się podstawowym instrumentem dopasowania działań podmiotów gospodarczych do zachodzących procesów wzrostu i zmian strukturalnych, a więc sposobem na efektywną realizację zamierzeń. Jego zastosowanie zwiększa ekonomiczną skuteczność działania na współczesnym rynku, gdyż wpływa pobudzająco na innowacyjne rozwiązania i wzmacnia konkurencyjną pozycję podmiotów gospodarczych. Stymulując możliwości postępu skłania do poszukiwania prekursorskich rozwiązań, kreowania nowych produktów i obszarów 
działalności. Stąd przydatność technik marketingu terytorialnego dla pobudzania aktywności ekonomicznej polskiej wsi oraz wspierania skuteczności podejmowanych dla jej rozwoju przedsięwzięć.

W opracowaniu podjęto próbę określenia możliwości wykorzystania marketingu terytorialnego we wspieraniu rozwoju terenów wiejskich. Wskazania potencjału, jaki kryje jego stosowanie dla stymulowania i upowszechniania postępu gospodarczego na wsi i ukazania potrzeby wypracowania dróg postępowania umożliwiających wykreowanie podejścia marketingowego jako immanentnej i efektywnej cechy rozwoju.

Orientację marketingową można zaliczyć do głównych czynników rozwoju gospodarczego na wsi, tym bardziej że sprzyja zarówno umiejętnościom tworzenia nowych, nieznanych wcześniej rozwiązań, jak i ich komercjalizacji. Chodzi tutaj przede wszystkim o długookresowy trend działalności, poparty praktycznym wykorzystaniem wykreowanych idei.

Marketing staje się dla funkcjonujących na wsi podmiotów podstawowym środkiem dopasowania ich działań do zachodzących procesów wzrostu i zmian strukturalnych, a więc sposobem efektywnej realizacji zamierzeń. Jego zastosowanie zwiększa ekonomiczną skuteczność działania na rynku poprzez stymulujący wpływ na możliwości akceptacji proponowanej oferty i stanowi kluczowy element rozwoju i wsparcia pozycji konkurencyjnej regionów wiejskich.

\section{Warunki rozwoju gospodarczego na wsi}

Obszary wiejskie wyróżniają się odmiennością sytuacji ekonomicznej i społecznej ich mieszkańców. Przestrzeń wiejska należy do obszarów o ograniczonym rozwoju gospodarczym wielu rejonów i znaczącym zapóźnieniu strukturalnym, zwłaszcza w regionach o najmniej korzystnym położeniu. Gospodarcze i społeczne zacofanie prowadzące do zaniedbania obszarów wiejskich oraz towarzyszące temu procesy migracyjne i związane $\mathrm{z}$ nimi dylematy potęgują problemy tych regionów i osłabiają ich pozycję. Ujawnia się przy tym wiele zjawisk społeczno-ekonomicznych hamujących bądź osłabiających możliwości rozwoju. Przejawy tych zjawisk są tym bardziej niepokojące, że zagospodarowanie przestrzeni silnie rzutuje na rozwój społeczno-gospodarczy, a jego znaczenie potęguje się wraz z postępującym zróżnicowaniem przestrzennym środowiska wiejskiego, przynoszącym wzrost złożoności i intensywności istniejących struktur przestrzennych.

Wiele terenów wiejskich znajduje się na peryferiach ekonomicznych, a ich systemy społeczne i funkcjonalne charakteryzuje niski poziom rozwoju. Ta sytu- 
acja powoduje, iż są stosunkowo naturalnym środowiskiem, o niezabudowanych gruntach rolnych i leśnych. Rzutuje to na priorytety społeczno-gospodarcze, do których w pierwszym rzędzie zalicza się utrzymanie walorów środowiska naturalnego. Obszary wiejskie pełnią jednak różnorodne funkcje gospodarcze. Rolnictwo dominuje wprawdzie nadal jako przestrzenna forma użytkowania powierzchni, aczkolwiek traci swoje znaczenie gospodarcze. Znaczenia nabierają pozarolnicze zawody i miejsca zatrudnienia, szczególnie te niekolidujące z zadaniem zachowania zasobów o charakterze ekologicznym. Ich rozwój na wsi postępuje jednak stosunkowo wolno. W efekcie konkurencyjność obszarów wiejskich jest osłabiona relatywnie niskimi zasobami gospodarczymi zarówno w odniesieniu do potencjału pracy, kapitału, jak i infrastruktury. Ponadto silniejsze ekonomiczne miasta pozyskują z tych terenów zasoby ekonomiczne stymulując swój wzrost ich kosztem. Szczególnie trudna jest sytuacja na obszarach słabo zaludnionych, o brakach infrastrukturalnych i niekorzystnej strukturze gospodarczej. Następujące przemiany przynoszą na obszarach i tak już słabo rozwiniętych dalsze osłabienie potencjału społeczno-ekonomicznego, bezrobocie, a także pogorszenie struktury demograficznej. Brakuje miejsc pracy, kurczy się rynek, ograniczana jest dostępność do szeregu usług. Kształtuje to negatywnie klimat społeczny i gospodarczy, rzutując ujemnie zarówno na inwestycje, jak i na konsumpcję ${ }^{1}$.

Słabo rozwinięte lokalne gospodarki mają zatem problem nie tylko z negatywnymi skutkami oddziaływania na siebie sfery gospodarczej i społecznej, ale i z pogłębianiem się nierówności przestrzennych. Obszary wysoko rozwinięte oferują więcej korzyści lokalizacji, są więc skuteczniejsze w utrzymywaniu i przyciąganiu inwestycji, pracowników, mieszkańców itp. Niewątpliwie nie rzutuje to pozytywnie na wiejskie gospodarki lokalne znajdujące się w innej fazie rozwoju. W efekcie pojawia się ryzyko powiększania się przepaści rozwojowych między peryferiami a centrami gospodarki. Pobudzanie rozwoju peryferii gospodarczych jest wobec tego bardzo istotne dla spójności społeczno-gospodarczej.

Obszary wiejskie, zajmujące ponad $93 \%$ powierzchni kraju i zamieszkane przez ok. 40\% ludności, nie mogą pozostawać marginalizowane. Niezbędna jest poprawa ich sytuacji, nadrobienie, choć częściowe, opóźnień w rozwoju. Niewątpliwie ogólny postęp cywilizacyjny, jaki następuje w kraju, niesie również pewną poprawę dla obszarów wiejskich, a zwłaszcza dla niektórych z nich. Wyraźny postęp nie dotyczy jednak zbyt wielu terenów. W odniesieniu do znacznej części tych obszarów nadal postępuje marginalizacja, rosną dysproporcje w stosunku do szybciej rozwijających się okolic. Przyczyn upatruje się w dużym wzroście

${ }^{1}$ J. Berbeka, Poziom życia ludności a wzrost gospodarczy w krajach Unii Europejskiej, Akademia Ekonomiczna w Krakowie, Kraków 2006, s. 39-41. 
produktywności i obniżaniu zatrudnia w tradycyjnych działach wytwarzania. Prowadzi to do polaryzacji niekorzystnej zarówno dla tych obszarów, jak i dla całej gospodarki. Coraz bardziej palącą kwestią staje się więc dostosowanie wsi do zachodzących zmian strukturalnych o podłożu ekonomiczny i technologicznym.

„Głównym problemem staje się zapoczątkowanie procesów umożliwiających rozwój, przełamanie peryferyjności i problemów gospodarczych związanych z dotychczasowymi strukturami i procesami gospodarczymi"’2. Potencjał tkwiący w rozwoju (nawet polegającym na silnym unowocześnieniu) tradycyjnych wiejskich funkcji gospodarczych nie tworzy wystarczających podstaw do pełnego uczestnictwa i korzystania przez tereny wiejskie z przemian dokonujących się we współczesnym świecie.

Możliwości rozwoju gospodarczego na wsi zależą od wielu czynników. U jego podłoża leży transformacja gospodarki kraju, przejście do realizacji gospodarki rynkowej. O ekonomicznym sukcesie bądź niepowodzeniu decyduje wyprofilowanie struktury gospodarczej wsi. We współczesnych uwarunkowaniach nacisk kładzie się przede wszystkim na odnowienie tej struktury. Odnowienie to może nastąpić na skutek oddziaływania zarówno sił wewnętrznych, jak i zewnętrznych.

Przez wiele lat przestrzeń wiejska odgrywała w gospodarce monofunkcyjną rolę. Egzystencja wsi i jej mieszkańców opierała się na rolnictwie (przy ciągle rosnącym zapotrzebowaniu na żywność), a pozostałe źródła dochodów miały przeważnie charakter uzupełniający. Rozwijała się wprawdzie dwuzawodowość, oparta była jednak na wahadłowej migracji do miast.

Przejście do gospodarki o orientacji rynkowej, po latach niedoborów i regulacji cenami umownymi, w szybkim tempie doprowadziło do zrównoważenia rynku żywnościowego, a następnie powstania znacznych nadwyżek podażowych. Jednocześnie drastycznie zmniejszyły się możliwości podjęcia pracy w miastach. Stało się tak w, zaostrzającej się w warunkach konkurencyjnych, sytuacji rosnących zagrożeń dla wsi stojącej przed wyzwaniami związanymi z przystąpieniem do Unii Europejskiej. Nadążanie za ekonomicznym rozwojem państw ją tworzących wiąże się z potrzebą wprowadzania zmian w terytorialnym podziale pracy, $\mathrm{z}$ innowacyjnymi rozwiązaniami, przemianami w rozmieszczaniu ludności i posiadanymi przez nią kwalifikacjami czy rozbudową infrastruktury.

Wymaga to wielu zmian o charakterze restrukturyzacyjnym. Zmiany w podłożu wiejskiego systemu gospodarczego, które mają doprowadzić do powodze-

2 T.G. Grosse, Wybrane koncepcje teoretyczne i doświadczenia praktyczne dotyczace rozwoju regionów peryferyjnych, [w:] Ekspertyzy przygotowane na potrzeby Strategii rozwoju spoteczno-gospodarczego Polski Wschodniej do roku 2020, Ministerstwo Rozwoju Regionalnego, www.mrr. gov.pl/rozwój regionalny 03.11.2012. 
nia strukturalnego dostosowania tego systemu w warunkach gospodarki rynkowej, opierają się w głównej mierze na rozwoju przedsiębiorczości. Rozwój zależy szczególnie od umiejętnego wykorzystania naturalnych zasobów wewnętrznych, a zwłaszcza tworzenia i wzbogacania kolejnych zasobów, które powiększą bazę aktywów danego regionu³. Wskazane jest pogłębienie zróżnicowania gospodarczej podstawy funkcjonowania obszarów wiejskich. Rozwój wsi wymaga zmian w strukturze gospodarczej. Nie wystarcza opieranie się na dotychczasowych produktach i osiągnięciach. Konieczne staje się wprowadzenie różnorodnych innowacji, zwłaszcza technologicznych, opartych na nowoczesnej wiedzy. To właśnie procesy innowacyjne zachodzące w przedsiębiorstwach, ich zdolność do wprowadzania oryginalnych rozwiązań, dają impuls do rozwoju obszarów, na których są zlokalizowane. Wyzwalają one ludzką kreatywność i zwiększają zdolności konkurencyjne.

Potrzebę nowych przedsięwzięć uzasadnia konieczność utrzymania relatywnie szybkiego tempa realizacji procesu restrukturyzacyjnego. Znaczną wagę przywiązuje się więc do uzupełnienia tkanki gospodarczej wsi nowymi, pozarolniczymi podmiotami gospodarczymi, wypełniającymi swą działalnością liczne luki utrudniające sprawne funkcjonowanie ekonomiki. Nowoczesność gospodarki na wsi oznacza jej zdolność do wytworzenia różnorodnych, nie tylko rolnych, produktów, na które istnieje zapotrzebowanie na rynkach światowych. Ten kierunek działań znajduje pełne odzwierciedlenie w głównych celach polityki Unii Europejskiej w odniesieniu do obszarów wiejskich. Obejmują one m.in. dywersyfikację działalności gospodarczej, wsparcie zakładania małych przedsiębiorstw, promowanie turystyki, ochronę zasobów naturalnych.

Na tym tle rodzą się konkretne potrzeby zmian w przestrzeni wiejskiej i ożywienia lokalnych źródeł rozwoju gospodarczego poprzez promowanie przedsiębiorczości, przysposobienie zawodowe do zatrudnienia na wsi, poszukiwanie i tworzenie dodatkowych źródeł dochodów bez konieczności opuszczania wsi. Potencjalny dynamizm gospodarczy obszarów wiejskich, rozwój różnych form przedsiębiorczości jest możliwy szczególnie teraz, gdy nowoczesna technika informacyjna może zrekompensować słabości życia wiejskiego, wynikające z dużych odległości i małej gęstości zaludnienia.

Do prowadzenia działań korzystnych dla rozwoju środowisk lokalnych, tworzonym firmom potrzebna jest łatwość integracji z otoczeniem, w którym powstają. Tym działaniom towarzyszą bowiem przemiany otoczenia, z jednej strony

${ }^{3}$ J. Pogorzelski, Praktyczny marketing miast i regionów, Wolters Kluwer, Warszawa 2012, s. 26 . 
stosunkowo szybkie, z drugiej nie w pełni przewidywalne, wprowadzające znaczny ładunek niepewności. Zdolność dostosowywania własnych zasobów do zmieniającego się otoczenia jest zaliczana do podstawowych warunków rozwoju jednostek terytorialnych ${ }^{4}$. Stanowi istotny czynnik zarówno w kontekście podejmowania inicjatyw lokalnych, jak i inicjatyw inwestycyjnych z zewnątrz. Dotychczas są one ograniczane brakiem kompetencji pracowników, niskim poziomem infrastruktury, niedogodnościami płynącymi z braku instytucji współpracujących, nie w pełni skuteczną pracą lokalnych władz samorządowych, niedostatecznym postępem rozwiązań legislacyjnych oraz małą dostępnością i zbyt wysokim oprocentowaniem kredytów inwestycyjnych. Konieczność poprawy pozycji konkurencyjnej rejonów wiejskich wymaga przeprowadzenia zmian, które umożliwiłyby zintensyfikowanie procesu dostosowawczego prowadzącego do trwałego i zrównoważonego rozwoju.

\section{Rola marketingu we wspomaganiu trwalego rozwoju lokalnego}

Rozwój lokalny następuje, gdy wcielane są w życie wartości cenione przez daną społeczność, jest kategorią dynamiczną, która wynika ze zmian zachodzących w osiąganym poziomie rozwoju. Rozwój oznacza bowiem zmianę poziomu odnoszącego się do osiągniętego $\mathrm{w}$ danym czasie stanu. Uzyskanie danego poziomu rozwoju rodzi chęć doprowadzenia do jego dalszego wzrostu, przeniesienia się na jego wyższy poziom.

Zjawisko to wiąże się z kategorią potrzeb. Potrzeba bowiem, to stan braku czegoś i zarazem czynnik uruchamiający funkcję motywu do działania w kierunku odpowiedniej zmiany tego stanu ${ }^{5}$. Brak nie musi odnosić się do zupełnego niezaspokojenia, lecz również do zaspokojenia realizowanego na zbyt niskim lub na nieodpowiedniej jakości poziomie. Wywołuje to dążenie do zaspokajania potrzeb na coraz wyższym poziomie.

Poziom zaspokojenia potrzeb opartych na wartościach danej lokalnej społeczności jest równoznaczny z poziomem rozwoju lokalnego. Biorąc to pod uwagę, uznać należy, że rozwój lokalny to dodatni, z punktu widzenia poziomu zaspo-

\footnotetext{
${ }^{4}$ S. Makieła, Przedsiębiorczość i innowacyjność - koncepcja i uwarunkowania rozwoju regionu, „Przegląd Organizacji” 2013, nr 2, s. 34.

${ }^{5}$ L. Rudnicki, Zachowania rynkowe nabywców. Mechanizmy i uwarunkowania, Wyd. Akademii Ekonomicznej w Krakowie, Kraków 2004, s. 36-37.
} 
kojenia potrzeb społecznych, bilans wyników zmian składu, cech oraz związków podmiotów i przedmiotów ${ }^{6}$ danej jednostki terytorialnej.

Zarządzanie wiejską przestrzenią ukierunkowane jest na osiąganie celów rozwojowych jednostki samorządowej. Jednostka samorządowa, ze względu na ustawowe ograniczenia, nie może podejmować bezpośrednich działań w zakresie wszystkich potrzeb swoich mieszkańców. Znaczna ich część zaspokajana jest przez podmioty spoza sfery samorządowej. Jednakże przydzielony samorządom zakres działania upoważnia do stwierdzenia, że celem tych jednostek jest bezpośrednie zaspokajanie tych potrzeb wspólnoty, co do których prawo nakazuje bądź zezwala podejmować działania, oraz stwarzanie warunków do możliwie najlepszego zaspokojenia tych potrzeb, wobec których jednostka nie ma kompetencji działania. Celem jest dbanie o racjonalne zaspokojenie potrzeb indywidualnych i zbiorowych w zakresie rozwoju duchowego i materialnego wspólnoty terytorialnej ${ }^{7}$. Ponadto należy mieć na uwadze, że jednostki samorządu terytorialnego zmuszone są do pojmowania działań konkurencyjnych z innymi obszarami.

W miarę nasilania procesów komercjalizacji w działalności samorządów jednostek terytorialnych wzrosło zainteresowanie metodami i technikami stosowanymi w walce konkurencyjnej przez podmioty gospodarcze ${ }^{8}$. Przyjmuje się coraz powszechniej orientację na klienta, mającą ułatwić samorządom osiąganie wyznaczonych celów.

Potrzebne staje się przestawianie gospodarki na bardziej otwarte, prorynkowe działania. Rozwój obszarów wiejskich, wzrost gospodarczy, wszechstronne przeobrażenie różnych dziedzin życia jest możliwe jedynie przy wykorzystaniu orientacji rynkowej wnoszącej znaczny ładunek innowacyjności, pozwalającej na przekształcenia o pozytywnym charakterze i ożywienie przestrzeni wiejskiej. Wprowadzającej zarazem zmiany o charakterze kumulacyjnym, gdzie każde następne posunięcie jest dodawane do poprzedniego. Ujawnia się potrzeba wspierania podejmowanych działań czynnikami intensyfikującymi możliwości wzmacniania pozycji konkurencyjnej. Należy bowiem dążyć do osiągania wymiernych korzyści. Stąd potrzeba stosowania nowoczesnych, innowacyjnych technik zarządzania, stymulujących, wspierających oraz podtrzymujących rozwój gospodarczy.

Podstawowym środkiem efektywnej realizacji takich zamierzeń staje się marketing. Jednostki administracji publicznej muszą bowiem uwzględniać

${ }^{6}$ E. Stańczyszyn, Uklad i rozwój lokalny, [w:] Gospodarka lokalna w teorii i praktyce, red. D. Strahl, Wyd. Akademii Ekonomicznej we Wrocławiu, Wrocław 2003, s. 135.

${ }^{7}$ A. Szromnik, Marketing terytorialny. Miasto i region na rynku, Wolters Kluwer, Kraków 2007, s. 12.

${ }^{8}$ S. Kauf, Zarzadzanie regionem w kreowaniu rozwoju społeczno-ekonomicznego, „Przegląd Organizacji” 2012, nr 7, s. 25. 
wymogi rynku - potrzeby i preferencje nabywców, a więc wprowadzać kompleksowo elementy marketingu, takie jak badania rynku oraz instrumenty marketingu $m i x^{9}$. Zasadniczym celem marketingu jest właśnie satysfakcja nabywców, będąca czynnikiem warunkującym osiągnięcie pożądanego celu. Przenosząc te rozważania na grunt samorządu - celem marketingu terytorialnego władz lokalnych jest satysfakcja klientów danego terytorium (w pierwszej kolejności społeczności lokalnej). Satysfakcja ta możliwa jest wyłącznie dzięki zaspokajaniu potrzeb na odpowiednim poziomie. Zaspokajanie potrzeb i pragnień jednostek i grup społecznych prowadzi do poprawy warunków ich życia. Jednocześnie zadowolenie i rozwój osób, grup i większych społeczności prowadzi do rozwoju całej jednostki osadniczej ${ }^{10}$. Marketing wpływa na zwiększenie wrażliwości organizacji na otoczenie. Dokonuje się tego poprzez poznanie potrzeb, pragnień, zachowań swoich klientów, konkurentów, partnerów, a także cech makrootoczenia - czyli dzięki wykorzystaniu kompleksowej wiedzy rynkowej implikującej zdolność do rozwiązywania problemów, do inteligentnego zachowania się i działania ${ }^{11}$.

Orientacja marketingowa staje się zatem najbardziej pożądanym podejściem podczas wspierania rozwoju lokalnego. Ważne są zwłaszcza korzyści rozwojowe, jakie można pozyskać dzięki jej przyjęciu. Szansa przyspieszenia zmian gospodarki wiejskiej tkwi w podniesieniu jakości posiadanych zasobów, poprzez wykorzystanie podejścia marketingowego propagującego atrakcyjniejsze sposoby postępowania. Postrzegany jest tutaj ogromny potencjał rewitalizacji wiejskiej przestrzeni zarówno niematerialnej, jak i materialnej ${ }^{12}$. Pozwala ona na tworzenie interesujących walorów niematerialnych, przyrodniczych i gospodarczych miejscowości wiejskich, a także sprzyja formowaniu aktywnej i zintegrowanej społeczności lokalnej. Wspierają to zmieniające się funkcje gospodarcze oraz techniki wytwórcze pozwalające na przeobrażenia i bardziej intensywne wykorzystanie przestrzeni wiejskiej, czyniąc ją bardziej atrakcyjną i zarazem otwartą na kolejne inwestycje. Rozwój gospodarczy wsi jest ponadto, w coraz większym stopniu, uzależniony od modernizowania i unowocześniania gospodarki. Pozwala to bowiem na niezbędne przemiany strukturalne. Podłożem tych przemian są nowoczesne przedsięwzięcia prorynkowe. Sprzyjają one zwłaszcza poprawie pozycji konkurencyjnej tych obszarów.

${ }^{9}$ Komunikacja i partycypacja społeczna, red. J. Hausner, Małopolska Szkoła Administracji Publicznej Akademii Ekonomicznej w Krakowie, Kraków, 1999, s. 53.

${ }^{10}$ A. Szromnik, op. cit., s. 17.

11 J. Gołuchowski, Przesłanki wykorzystania technologii wiedzy w zarzadzaniu publicznym, [w:] Zarzadzanie publiczne - elementy teorii i praktyki, red. A. Frączkiewicz-Wronka, Wyd. Akademii Ekonomicznej w Katowicach, Katowice 2009, s. 107.

12 S. Komosiński, Praktyka marketingu terytorialnego w dziejach, „Marketing i Rynek” 2012, nr 2, s. 10 . 
Dodatkowy atut zastosowania marketingu na szczeblu zarządzania społecznościami lokalnymi wynika z potrzeby znalezienia nowych sposobów podnoszenia efektywności działań, dającej gwarancję trwałości rozwoju. Podejście marketingowe ma tę efektywność znacząco zwiększyć. Jest to o tyle istotne, że w warunkach ograniczonych zasobów wewnętrznych oraz silnej konkurencji o zasoby zewnętrzne, właśnie od efektywności ich wykorzystania i zdobywania zależeć będzie rozwój jednostki. Najprostszym sposobem podnoszenia efektywności działań jest redukowanie dysonansu, jaki istnieje pomiędzy oczekiwaniami i potrzebami danej społeczności a sposobem zaspokojenia tych potrzeb i oczekiwań przez proponowaną im ofertę ${ }^{13}$. Wszędzie tam, gdzie konkurencja wymusza racjonalizację działań, a czynnikiem decydującym o sukcesie jest zadowolenie szeroko rozumianych klientów, zasadne staje się wdrożenie orientacji marketingowej. W przypadku marketingu terytorialnego można mówić zatem o nakierowaniu na efektywne, społeczne i ekonomiczne funkcjonowanie terytorium, zgodnie z szerszymi, wytyczonymi celami ${ }^{14}$.

Marketing może służyć rozwojowi kierując się wartościami cenionymi przez całą lokalną społeczność. Opiera się na dążeniu do zaspokojenia potrzeb środowiska społeczno-ekonomicznego danego terytorium w odniesieniu do interesu publicznego. Oferuje metody i narzędzia dla wsparcia jego rozwoju i dobrobytu. Jego zadaniem jest pozyskiwanie i zarządzanie zasobami rozwojowymi celem wcielenia w życie lokalnych wartości. Winien on sprzyjać harmonizowaniu rozwoju lokalnego poprzez oddziaływanie na osiąganie postępu cywilizacyjnego i pełniejszej egzystencji. Tego typu orientacja, prorynkowa i proprzedsiębiorcza może służyć harmonizacji rozwoju lokalnego w tym większym stopniu, im bardziej niejednoznaczne jest środowisko działania gminy, im bardziej skomplikowany wewnętrznie jest jej układ społeczno-gospodarczy ${ }^{15}$. Przed marketingiem stoi więc zadanie budowania indywidualnych ścieżek rozwojowych w ramach idei trwałego i zrównoważonego rozwoju wiejskich jednostek przestrzennych.

${ }^{13}$ T. Domański, Marketing terytorialny - wybrane aspekty praktyczne, [w:] Marketing terytorialny. Strategiczne wyzwania dla miast i regionów, red. T. Domański, Wyd. Uniwersytetu Łódzkiego, Łódź 1997, s. 20.

${ }_{14}$ J.R. Gold, S.V. Ward, Place Promotion - the Use of Publicity and Marketing to Sell Towns and Regions, John Wiley and Sons, Chichester 1994, s. 41.

${ }_{15}$ S. Barczyk, Przedsiębiorczość samorzadu lokalnego w ponowoczesnym przedsiębiorstwie, „Organizacja i Kierowanie” 2011, nr 3, s. 205. 


\section{Marketingowa orientacja zarządzania wiejskimi jednostkami terytorialnymi}

Marketing terytorialny to koncepcja zarządzania jednostką terytorialną według orientacji marketingowej ${ }^{16}$, termin orientacja rynkowa oznacza zaś stopień wdrożenia zasad marketingu ${ }^{17}$. Zasięg orientacji rynkowej wpływa bezpośrednio na możliwość marketingowego zarządzania jednostką przestrzenną, które zdeterminowane jest wiedzą o rynku. Kluczową dla marketingu zasadą jest bowiem podejmowanie decyzji według potrzeb zainteresowanych. Marketing terytorialny opiera się na wspólnocie interesów i odpowiednich relacjach między zainteresowanymi podmiotami. Wykorzystuje relacje zachodzące na danym terytorium i utożsamia się z jego wartościami oraz unikatową ofertą. Zasięg orientacji marketingowej wpływa na skuteczność wykorzystywanych instrumentów, a te z kolei na efekty działalności organizacji. Rozwój lokalny może być więc, dzięki zwiększonemu zasięgowi orientacji rynkowej, realizowany w większym stopniu.

Stąd ważne jest pełniejsze wykorzystanie i zintegrowane oddziaływanie instrumentami marketingowymi, wykorzystywanie ich jako zestawu działań, za pomocą których dana jednostka przestrzenna zamierza osiągnąć swoje długofalowe cele na rynku. Ich realizacja wymaga ciągłości podejścia oraz dużej elastyczności w stosunku do zmian otoczenia. Działania te opierają się na podstawowych instrumentach marketingowych: produkcie, cenie, dystrybucji i promocji.

Podejście rynkowe sprawia, że jednostki wiejskie są postrzegane jako podmioty kreujące konkurencyjność oferowanego produktu. Wzmacnia więc przyciąganie potencjału jednostki terytorialnej oraz wyzwala nowe jego przejawy. Produkt jednostki terytorialnej stanowią jego specyficzne, indywidualne cechy, ukształtowane na przestrzeni lat. Wyraża się on o wiele większą złożonością niż koncepcja produktu $\mathrm{w}$ tradycyjnym rozumieniu ekonomicznym ${ }^{18}$.

Marketingowe wsparcie dla takiego produktu wymaga kompleksowego podejścia. Jest ono jednak, wobec różnorodności i kompleksowości zawartości obiektu, często nadmiernie uproszczone i prowadzi do aktywizacji jedynie jednostkowych, aczkolwiek atrakcyjnych przedsięwzięć. Przejawy takiego postępowania zachodzą w ograniczonej postaci, np. standardowa kampania promocyjna

${ }^{16}$ M. Florek, Podstawy marketingu terytorialnego, Wyd. Akademii Ekonomicznej w Poznaniu, Poznań 2007, s. 19.

${ }^{17}$ A.K. Kohli, B.J. Jaworski, Market orientation: The construct, research propositions, and managerial implications, „Journal of Marketing” 1990, vol. 54, s. 1.

${ }_{18}$ F. Daňo, E. Homuláková, D. Vokunowa, Marketing jako instrument polityki komunalnej, „Marketing i Rynek” 2003, nr 10, s. 10. 
dla poprawy znajomości rejonów turystycznych, planowanie i realizacja atrakcyjnych imprez bez zintegrowanego rozwoju produktu, poprzez poprawę infrastruktury, wszechstronnych powiązań pomiędzy podmiotami, zabezpieczenia strony prawnej itp. Fragmentaryczne, niepełne stosowanie pojedynczych elementów marketingu nie przyniesie oczekiwanych skutków.

Głównie uwagę wypada skoncentrować na tych elementach wiejskiej jednostki terytorialnej, które mogą stanowić czynnik napędowy dla przystosowania instrumentów marketingowych do specyfiki danego obszaru. Do podstawowych czynników stanowiących o konkurencyjności oferty należą: środowisko gospodarcze i społeczne, obecność przedsiębiorstw innowacyjnych, zwłaszcza, co jest rzadkością na polskiej wsi, jednostek technologicznie zaawansowanych, dostępność przestrzenna oraz jakość usług publicznych. Trzeba więc uwzględnić zwiększenie roli aktywności pozarolniczej i dążenie do pełniejszego wykorzystania posiadanych zasobów. Odmienności rejonów wiejskich wymagają uwzględnienia:

- lokalnej i branżowej specyfiki instrumentów marketingowych (np. marketing dla centrów zakupu, marketing dla współdziałania na imprezach handlowych);

- nowych płaszczyzn i perspektyw wykorzystania instrumentów marketingowych (np. w administracji publicznej i organizacjach non-profit);

- pozamarketingowych elementów oddziaływania rzutujących na możliwości postępowania marketingowego (np. procesy polityczne, rozwój wsi, inwestycje infrastrukturalne, polityka medialna);

- strony organizacyjnej prowadzonej działalności, uzależnionej od zadań nastawionych na obsługę zewnętrznych klientów (np. logistyka obsługi i infrastruktura transportu);

- adekwatnych branżowo instrumentów uzależnionych od przyjętego zakresu działalności, jak usługi (turystyka, kultura), rynek dóbr przemysłowych (współuczestnictwo, współpraca przedsiębiorstw), organizacje non-profit;

- specyfiki kontekstu marketingowych instrumentów (kultura, sport itp.).

Posiadane atuty wpływają na wizerunek wiejskiej jednostki przestrzennej, pozwalając wypracować jej markę. Wykreowana może zostać oferta, która umożliwi jej zaistnienie na rynku. Marka pozwoli zidentyfikować i ułatwić rozpoznawanie korzyści płynących z oferty rejonu i jego podmiotów oraz zwiększyć zainteresowanie nim na zewnątrz, co spotęguje jego znaczenie.

Samorządy terytorialne posiadają znaczne kompetencje w zakresie udzielania przedsiębiorcom zachęty finansowej. Mogą więc prowadzić aktywną politykę cenową. Przyjmuje ona charakter bezpośredni (np. w postaci subwencji na tworzenie nowych przedsiębiorstw i nowych miejsc pracy) lub pośredni (np. może 
dotyczyć rabatów przy zakupie bądź wynajmie budynków z danych terenów dla celów produkcyjnych, usługowych czy okresowych zwolnień od podatków lokalnych). Samorządowe władze wiejskich jednostek terytorialnych mogą dążyć do uczynienia swej oferty konkurencyjną cenowo w porównaniu z innymi ofertami, celem pozyskania inwestorów. Ustalane są ulgi dla przedsiębiorstw zwiększających zatrudnienie, obniża się stawki podatku na budynki i grunty, związane z działalnością gospodarczą. Do przywilejów finansowych zalicza się także prawo pierwokupu lokali użytkowych i mieszkalnych przez najemców i dzierżawców, często na zasadach sprzedaży ratalnej. Tego typu ulgi i bonifikaty mogą występować w wielu wariantach. Możliwość znaczącego ich różnicowania przez poszczególne jednostki terytorialne stanowi istotny atut polityki cenowej.

Dystrybucja wartości i zasobów jednostek przestrzennych jest powiązana z rozmieszczeniem działalności w przestrzeni oraz z dostępnością wewnętrzną i zewnętrzną danego rejonu. Podstawowe cele dystrybucji prowadzonej przez władze lokalne sprowadzają się do rozszerzenia dostępu do oferowanych produktów oraz ułatwienia ich zbycia. Charakterystyczną właściwością dystrybucji w marketingu terytorialnym jest możliwość udostępniania wielu produktów jedynie w miejscu ich występowania. Stąd w dystrybucji szczególne znaczenie zyskuje informacja, jako że zakup odbywa się często w znacznej odległości od miejsca konsumpcji ${ }^{19}$. Szybki i względnie łatwy dostęp do informacji, przy wykorzystaniu technologii informatycznej i nowoczesnych systemów elektronicznych, będzie sprzyjał uzyskaniu przewagi konkurencyjnej przez daną jednostkę przestrzenną. Obok bezpośrednich powiązań z ewentualnymi kontrahentami, znaczenia nabierają i wymagają równoległego rozwoju także powiązania $\mathrm{z}$ wykorzystaniem ogniw pośredniczących. Mogą one być dwojakiego rodzaju: wyspecjalizowane firmy doskonale znające poszczególne rynki i umiejętnie się na nich poruszające bądź instytucje pozarządowe (agencje, fundacje) oficjalnie wspierające działania poszczególnych jednostek przestrzennych, udzielające gwarancji, wsparcia finansowego itp.

U podstaw działań promocyjnych leżą potrzeby komunikacji wiejskiego samorządu terytorialnego z rynkiem. Jest to zazwyczaj relatywnie najintensywniej wykorzystywany przez jednostki terytorialne instrument marketingowy. Podkreślana jest różnorodność instrumentów i form promocji ukierunkowana zarówno na zewnątrz jednostek terytorialnych, jak i do ich wnętrza ${ }^{20}$. Istnieje konieczność utworzenia odpowiedniego przekazu w odniesieniu do wsi. Instytucjonalnie opie-

${ }^{19}$ M. Rawski, Wybrane teoretyczne i praktyczne problemy tworzenia strategii w marketingu terytorialnym, „Zeszyty Naukowe Uniwersytetu Ekonomicznego w Krakowie” 2009, nr 804, s. 83.

${ }^{20}$ S. Makarski, W. Kuźniar, Marketing w zarzadzaniu jednostka terytorialna. Na przykładzie województwa podkarpackiego, Wyd. Uniwersytetu Rzeszowskiego, Rzeszów 2012, s. 178. 
ra się on w zasadzie na pracownikach od spraw promocji gospodarczo-kulturalnej. Do najczęściej wykorzystywanych instrumentów w promocji jednostek terytorialnych zalicza się reklamę i public relations. Pewne możliwości dają różnego rodzaju targi, w których mogą uczestniczyć wiejskie jednostki terytorialne. Są one stosunkowo uniwersalnym narzędziem promocji, gdyż pozwalają na stosowanie zarówno instrumentów z zakresu reklamy, public relations, jak i sprzedaży osobistej, co wzmacnia siłę ich oddziaływania. Jednak takich imprez dostępnych dla wiejskich gmin nie ma w Polsce zbyt wiele. Gminy wiejskie mogą się nagłaśniać ponadto poprzez organizację imprez kulturalnych, folklorystycznych czy związanych z tradycjami regionalnymi.

Wiejskie jednostki terytorialne, jako wytyczone z wykorzystaniem funkcjonalno-przestrzennych kryteriów podmioty rynkowe, są kompleksowym produktem opartym na różnorodnych i równoczesnych atrybutach, powiązanych z możliwością aktywnego oddziaływania na ich podstawie. W ramach tych jednostek mogą występować różne przejawy działalności rzutujące na dobór środków marketingowych i zakres ich stosowania. Uwagę należy skoncentrować głównie na tych elementach wiejskiej jednostki terytorialnej, które mogą stanowić czynnik napędowy dla przystosowania instrumentów marketingowych do specyfiki danego obszaru. Opracowanie koncepcji marketingowej dla danej jednostki terytorialnej powinno być więc zespolone z jej programem rozwoju. Wymaga to stworzenia odpowiedniej oferty dostarczającej adresatom działań marketingowych satysfakcjonujących wartości w sposób bardziej efektywny niż jednostki konkurencyjne ${ }^{21}$. Marketing terytorialny opiera się na relacji z danym terytorium i utożsamianiu się z jego wartościami oraz unikatową ofertą. Podejście rynkowe sprawia, że jednostki wiejskie są postrzegane jako podmioty kreujące własną konkurencyjność.

Realizatorem działań z zakresu marketingu terytorialnego na obszarach wiejskich może być gmina, miasteczko, powiat, a więc jednostki terytorialne tworzące podmiot o powiązaniach przestrzenno-społeczno-gospodarczych. Aktywność marketingowa w tych jednostkach może przebiegać w następujących etapach ${ }^{22}$ :

- analiza lokalnego systemu oraz jego pozycjonowania w odpowiednim środowisku konkurencyjnym i kooperatywnym, przy wykorzystaniu perspektywy dynamicznej;

- zdefiniowanie procesów i ścieżek migracji dla lepszego rozwoju systemu lokalnego, które zaktywizują środki finansowe na wykorzystanie lokalnych zasobów i głównych atutów;

${ }^{21}$ Ibidem, s. 176.

${ }^{22}$ V. Zuchella, S. Denicolai, Marketing terytorialny i zarządzanie strategiczne $w$ rozwoju lokalnym, [w:] Marketing terytorialny, red. H. Szulce, M. Florek, Wyd. Akademii Ekonomicznej w Poznaniu, Poznań 2005, s. 34. 
- zdefiniowanie spójnego podejścia marketingu terytorialnego oraz działań marketingowych.

Pozwoli to wypracować korzystniejszą pozycję konkurencyjną wobec podmiotów zewnętrznych, wymaga jednak dokonania konkretnych posunięć. Nie można się ograniczyć do powierzchownych bądź fragmentarycznych dokonań. To byłoby zdecydowanie zbyt mało, aby sprostać wymogom konkurencyjnego rynku.

Uzasadnione jest podjęcie bardziej znaczących i wszechstronnych działań, tak, aby mogły one stanowić impuls do dalszego rozwoju gospodarczego. Istnieje potrzeba rozwijania współpracy na różnych obszarach aktywności gospodarczej. Ograniczanie się do pojedynczych akcji nie może przynieść zainteresowanym znaczących korzyści. Posunięcia marketingowe nie powinny być zawężane i ujmowane $\mathrm{w}$ formie powszechne przyjętych standardów. Mają bowiem doprowadzać do wypracowania, opartej na lokalnych zasobach, przewagi konkurencyjnej.

Ważne jest przy tym uwzględnienie silnych stron obszarów wiejskich i skuteczności doboru marketingowych instrumentów konkurowania. Działania w tym zakresie mają na celu ${ }^{23}$ :

- w pierwszej kolejności zmniejszenie barier ograniczających lub zwiększenie zdolności absorpcyjnej;

- w następnej, wsparcie współpracy miedzy lokalnymi instytucjami;

- w fazie końcowej, dążenie do utworzenia unikatowej i niepowtarzalnej kombinacji zdolności lokalnych instytucji i lokalnych zasobów, zintegrowanych w razie konieczności z zewnętrznymi zasobami oraz źródłami wiedzy.

Muszą mieć one charakter procesu innowacyjnego, gdyż tylko utrzymanie innowacyjności w działaniach marketingowych może przynieść korzyści w postaci silnej pozycji konkurencyjnej. Stanowi ona kluczowy element uzyskania przewagi konkurencyjnej, pozwalający na osiągnięcie wiodącej pozycji na rynku. Oznacza bowiem możliwość wprowadzania, kreowania i upowszechniania nowych rozwiązań. Sukces marketingu polega na zdolności przystosowania się do podobnych, ale zmieniających się sytuacji.

\section{Zakończenie}

Marketing stanowi kluczowy element rozwoju obszarów wiejskich. Skuteczne wprowadzenie i upowszechnianie marketingu terytorialnego sprzyja osiąganiu w miarę zrównoważonego rozwoju wsi, modernizacji jej potencjału ekonomicz-

${ }^{23}$ Ibidem, s. 37. 
nego i jego efektywnemu wykorzystaniu. Tereny wiejskie cechuje jednak przeważnie niekorzystny poziom rozwoju sfer społecznych i ekonomicznych. W tej sytuacji marketing terytorialny ma niewątpliwie trudniejsze zadanie niż w przypadku terenów charakteryzujących się wysokim stopniem rozwoju. Mimo wszystko wydaje się, że w zestawieniu $\mathrm{z}$ istniejącymi możliwościami wykorzystanie marketingu terytorialnego na obszarach wiejskich okazuje się stosunkowo powolne. Większość działań (jeśli już są wprowadzane) jest oparta na standardowych czynnościach, koncepcjach i zasadach wykorzystanych w danym środowisku. Odczuwa się brak odpowiednio szerokiego zestawu wspierających się wzajemnie nowoczesnych oddziaływań związanych z procedurami, organizacją i finansami.

Powinny one zostać ukierunkowane na poszczególne rejony wiejskie, z uwzględnieniem ich odmienności oraz wprowadzanych przez nie nowości. W każdym z nich należy wyróżniać cechy charakterystyczne, na które składają się elementy marketingu-mix oraz specyficzne właściwości. Istotnym problemem staje się określenie segmentów rynku, ich granic i wielkości, jak również badanie pożądanych powiązań rynkowych. Szybko wzrasta rola wsparcia promocyjnego, stając się niejednokrotnie odczuwalnym warunkiem zaakceptowania innowacji ukierunkowanej na wzbogacenie oferty. Jednocześnie wymagane jest systemowe podejście do wykorzystania instrumentów marketingowych.

Oczekiwane pozytywne zmiany w dłuższym okresie ulegną spotęgowaniu, bardziej skutecznemu dzięki zastosowaniu instrumentów marketingowych. Postępowanie marketingowe przyniesie zapewne pozytywne rezultaty, sprzyjające poprawie konkurencyjności, zyskowności oraz dalszemu aktywnemu rozwojowi obszarów wiejskich. Oczekiwane efekty można uzyskać za pomocą różnych konkretnych rozwiązań. W miarę potrzeb działania marketingowe można zarówno łączyć, jak i rozgraniczyć. Szczególnie pozytywne skutki może bowiem przynieść zintegrowane wykorzystanie kombinacji wielu różnych instrumentów. Mają one stwarzać zachętę do inwestowania w innowacje i podejmowania ryzyka przedsiębiorczego, co będzie sprzyjać, dzięki efektom synergicznym, wzmożonemu ożywieniu innowacji w poszczególnych dziedzinach gospodarowania.

Stąd potrzeba wszechstronnego wsparcia m.in. poprzez wzmacnianie rozwoju instytucjonalnego, kształtującego warunki sprzyjające aktywności gospodarczej mieszkańców wsi. Szczególnie ważne dla stymulowania działań marketingowych jest wspieranie podmiotów gospodarczych przez sektor publiczny. Okazuje się to tym istotniejsze, że absorpcja orientacji marketingowej napotyka barierę w postaci trwałości wiejskich struktur społecznych i gospodarczych. Dla wprowadzania i rozpowszechniania orientacji marketingowej potrzebne jest aktywne podejście organów władzy państwowej, zwłaszcza samorządów terytorialnych. 
Jest przy tym bardzo wskazane umożliwienie pełnego wykorzystywania oddziaływania środków marketingowego przez małe i średnie lokalne przedsiębiorstwa. Dotyczy to szczególnie tych położonych na słabo rozwiniętych ekonomicznie terenach wiejskich. Rosnące wymogi wskazują na potrzebę rozbudowy zakresu i jakości elementów orientacji marketingowej. Potrzebna jest przede wszystkim bogata wiedza rynkowa odnosząca się do potrzeb społecznych, której samorządom wiejskich jednostek terytorialnych często wyraźnie brakuje. Konsekwencje tego są wielorakie i prowadzą do ograniczonej trafności i efektywności wykorzystywania środków, co niepokoi tym bardziej w sytuacji, gdy w gospodarce procesy rozwojowe przyspieszają i opierają się na kreowaniu innowacyjności.

Korzystanie ze środków marketingowych powinno się koncentrować na tych, które mogą stanowić czynnik dynamizujący podejście marketingowe, aby skutecznie wspierać trwały i zrównoważony rozwój danego obszaru. Wykorzystanie orientacji marketingowej jest jednak przede wszystkim uwarunkowane docenieniem jej użyteczności przez władze odpowiedzialne za rozwój danej społeczności.

Postęp w dużej mierze zależy od samorządów i przeznaczania przez nie środków finansowych na przedsięwzięcia pozwalające zmobilizować środki umożliwiające wprowadzanie działań służących rozwojowi. Stąd potrzeba silnego oddziaływania i wsparcia ze strony organów administracji i organizacji pozarządowych na terenach wiejskich. Na rynku najistotniejszy jest sukces komercyjny. Podstawę tego sukcesu stanowi użyteczność stosowanych metod i środków. Działania wymagają więc ukierunkowania na zwiększenie zdolności wchłaniania i wdrażania zasad postępowania marketingowego na wsi. Pozwoli to przyśpieszyć proces dyfuzji na terenach wiejskich. Dzięki temu ułatwione będzie prowadzenie działań na rzecz podtrzymania i spotęgowania tendencji rozwojowych tych obszarów.

\section{Bibliografia}

Barczyk S., Przedsiębiorczość samorzadu lokalnego w ponowoczesnym przedsiębiorstwie, „Organizacja i Kierowanie” 2011, nr 3

Berbeka, J., Poziom życia ludności a wzrost gospodarczy w krajach Unii Europejskiej, Akademia Ekonomiczna w Krakowie, Kraków 2006

Daňo F., Homuláková E., Vokounova D., Marketing jako instrument polityki komunalnej, „Marketing i Rynek” 2003, nr 10

Domański T., Marketing terytorialny - wybrane aspekty praktyczne, [w:] Marketing terytorialny. Strategiczne wyzwania dla miast i regionów, red. T. Domański, Wyd. Uniwersytetu Łódzkiego, Łódź 1997

Florek M., Podstawy marketingu terytorialnego, Wyd. Akademii Ekonomicznej w Poznaniu, Poznań 2007 
Gold J.R., Ward S.V., Place Promotion - the Use of Publicity and Marketing to Sell Towns and Regions, John Wiley and Sons, Chichester 1994

Gołuchowski J., Przestanki wykorzystania technologii wiedzy $w$ zarzadzaniu publicznym, [w:] Zarzadzanie publiczne - elementy teorii i praktyki, red. A. Frączkiewicz-Wronka, Wyd. Akademii Ekonomicznej w Katowicach, Katowice 2009

Grosse T.G., Wybrane koncepcje teoretyczne i doświadczenia praktyczne dotyczace rozwoju regionów peryferyjnych, [w:] Ekspertyzy przygotowane na potrzeby Strategii rozwoju społeczno-gospodarczego Polski Wschodniej do roku 2020, Ministerstwo Rozwoju Regionalnego, www.mrr.gov.pl/rozwój regionalny 03.11 .2012

Kauf S., Zarzadzanie regionem w kreowaniu rozwoju spoleczno-ekonomicznego, „Przegląd Organizacji” 2012, nr 7

Kohli A.K., Jaworski B.J., Market orientation: The construct, research propositions, and managerial implications, „Journal of Marketing” 1990, vol. 54

Komosiński S., Praktyka marketingu terytorialnego w dziejach, „Marketing i Rynek" 2012, nr 2

Komunikacja i partycypacja społeczna, red. J. Hausner, Małopolska Szkoła Administracji Publicznej Akademii Ekonomicznej w Krakowie, Kraków 1999

Makarski S., Kuźniar W., Marketing w zarządzaniu jednostka terytorialnq. Na przyktadzie województwa podkarpackiego, Wyd. Uniwersytetu Rzeszowskiego, Rzeszów 2012

Makieła Z., Przedsiębiorczość i innowacyjność - koncepcja i uwarunkowania rozwoju regionu, „Przegląd Organizacji” 2013, nr 2

Pogorzelski J., Praktyczny marketing miast i regionów, Wolters Kluwer, Warszawa 2012

Rawski M., Wybrane teoretyczne i praktyczne problemy tworzenia strategii $w$ marketingu terytorialnym, ,Zeszyty Naukowe Uniwersytetu Ekonomicznego w Krakowie" 2009, nr 804

Rudnicki L., Zachowania rynkowe nabywców. Mechanizmy i uwarunkowania, Wyd. Akademii Ekonomicznej w Krakowie, Kraków 2004

Stańczyszyn E., Układ i rozwój lokalny, [w:] Gospodarka lokalna w teorii i praktyce, red. D. Strahl, Wyd. Akademii Ekonomicznej we Wrocławiu, Wrocław 2003

Szromnik A., Marketing terytorialny. Miasto i region na rynku, Wolters Kluwer, Kraków 2007

Zuchella A., Denicolai S., Marketing terytorialny i zarzadzanie strategiczne w rozwoju lokalnym, [w:] Marketing terytorialny, red. H. Szulce, M. Florek, Wyd. Akademii Ekonomicznej w Poznaniu, Poznań 2005 